\title{
In a Poor State: The Long RoAd to Human Rights Protection ON THE BaSis OF Social CONDITION
}

\author{
LYNN A. IDING*
}

This article examines how poverty in Canada might be alleviated with different forms of human rights protection that include protection from discrimination on the basis of social condition. Social condition discrimination could include denial of goods and services based on stereotypes of poverty, or could include disadvantage resulting from actual inability. to pay. If based only on stereotypes, the author argues, social condition would be differentiated from other grounds of discrimination. Poor people need to be protected from the prejudice of others as well as the effects of being poor, and this may be accomplished by incorporating full social condition protection in both human rights legislation and the Canadian Charter of Rights and Freedoms. Canada has international obligations concerning poverty, and those obligations are sometimes recognized by the courts in their decisions. However, economic rights have been consistently rejected as having Charter protection, perhaps out of fear that courts would be commanding the government to create or alter social programs. The author concludes that the Charter might still be the most effective place for economic rights, placing the initial onus more on the public sphere, which would at the same time consequently distribute some of the financial burden in the private sphere.
Cet article examine quelques façons de réduire la pauvreté au Canada au moyen de différentes formes de protection des droits de la personne incluant la protection contre la discrimination en raison de la condition sociale. La discrimination en raison de la condition sociale comprend le déni de biens et de services basé sur les stéréotypes relatifs à la pauvreté ou encore, elle pourrait comprendre les inconvénients causés par une incapacité de payer. Si elle est basée uniquement sur les stéréotypes, alors l'auteur estime qu'il faudrait faire une distinction entre la condition sociale et les autres raisons de discrimination. Il faut protéger les gens pauvres des préjudices des autres et de l'effet de l'état d'être pauvre en incorporant la pleine protection de la condition sociale dans la législation sur les droits de la personne et la Charte canadienne des droits et libertés. Le Canada a des obligations internationales relatives à la pauvreté et les tribunaux reconnaissent parfois ces obligations dans leurs décisions. Cependant, on a toujours refusé d'accorder la protection de la Charte aux droits économiques, peut-être par crainte que les tribunaux n'ordonnent au gouvernement de créer ou de modifier les programmes sociaux. L'auteur conclut que le recours à la Charte constitue peut-être toujours la meilleure démarche pour protéger les droits économiques, plaçant l'emphase sur la scène publique ce qui, par conséquent, permettrait en même temps de répartir le fardeau financier sur la scène publique.

\section{TABLE OF CONTENTS}

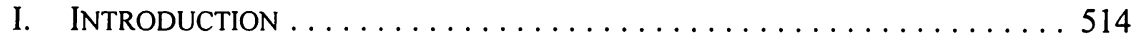

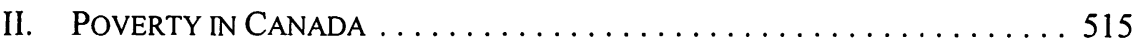

III. WHAT IS SOCIAL CONDITION? $\ldots \ldots \ldots \ldots \ldots \ldots \ldots \ldots \ldots \ldots \ldots$

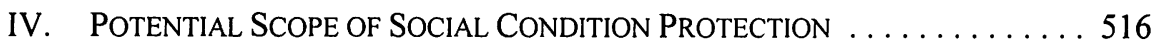

V. INCONSISTENCY WITH EXISTING

HUMAN RIGHTS JURISPRUDENCE . . . . . . . . . . . . 517

VI. "UNFETTERED CAPITALISM" AS A BASIS FOR

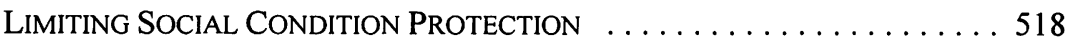

VII. LAYING THE FOUNDATION FOR ECONOMIC RIGHTS:

INTERNATIONAL LAW AND CANADA'S OBLIGATIONS . . . . . . . . . 520

Lynn Iding completed her articles at Torys LLP in June 2003, and will be clerking at the Ontario Superior Court of Justice this fall. The opinions expressed in this article are those of the author and do not necessarily represent those of the Court or the Ministry of the Attorney General. The author would like to thank Charmaine Iding for editorial assistance. 


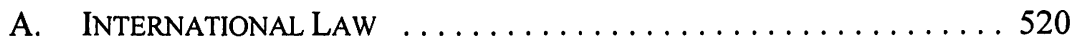

B. JUDICIAL REFERENCE TO THE RELEVANCE OF

INTERNATIONAL HUMAN RIGHTS LAW . . . . . . . . . . . . 521

VIII. JUDICIAL RECOGNITION OF SOCIAL CONDITION $\ldots \ldots \ldots \ldots \ldots \ldots . \ldots 21$

IX. IS THE CHARTER THE PROPER PLACE FOR THE

PROTECTION OF ECONOMIC RIGHTS? . . . . . . . . . . . . . . . . . . 524

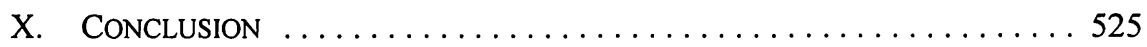

\section{INTRODUCTION}

The divide between the rich and the poor in Canada is widening. The standard of living for the nation's poorest is declining while the net worth of the wealthiest is growing. ' Citizens living in poverty comprise perhaps one of the most viciously vilified groups in society. The time for concrete recognition of social condition as a prohibited ground of discrimination in Canada may be long overdue. Many commentators have made convincing arguments that poverty or social condition should be included in human rights legislation or read in as an analogous ground under s. 15 of the Canadian Charter of Rights and Freedoms, ${ }^{2}$ or that basic economic rights should be included under s. $7 .^{3}$ Less often explored, however, is how social condition protection would operate given its unique qualities, and whether inclusion in human rights legislation alone would truly move forward in a significant way the struggle for substantive equality and reduction of poverty and its devastating consequences. Due to societal, legislative, and judicial hesitance to alter the basis of a capitalist, market-driven economy which by very definition ensures economic inequality, anti-discrimination legislation in itself might result in only the limited effect of addressing stereotypes about low income individuals, while doing little to alleviate poverty itself and its barriers to accessing necessities of life. Ensuring that economic disadvantage is addressed in a substantive way may require the entrenchment in Canadian jurisprudence of positive economic rights. Such a development would move further toward substantive equality for Canada's economically disadvantaged, and be in accordance with Canada's international commitments to ensure that every citizen has the right to life's necessities and the inherent dignity that comes with economic self-determination. While anti-discrimination provisions in human rights legislation would be a step in alleviating some of the effects of poverty in the private sector, positive economic rights might be more practically enshrined in the Charter, where the common law human rights framework has already set the stage for expansion to social condition protection. Given the crisis of poverty in Canada and Canada's international commitments, the question is not whether to proceed, but how?

Elaine Carey, "Rich, poor are even wider apart" Toronto Star (16 March 2001) Al.

Part I of the Constitution Act, 1982, being Schedule B to the Canada Act 1982 (U.K.), 1982, c. 11 [Charter].

See Martha Jackman, "Constitutional Contact with the Disparities in the World: Poverty as a Prohibited Ground of Discrimination under the Canadian Charter and Human Rights Law" (1994) 2 Rev. Const. Stud. 76. See also William Black \& Lynn Smith, "Case Comment on Andrews v. Law Society of British Columbia" (1989) 68 Can. Bar Rev. 591 at 607. 


\section{Poverty in Canada}

Despite Canada's relative wealth on an international scale, lower income Canadians face barriers in virtually all facets of society from employment and access to services to housing. Banks, for example, often require extensive identification to open an account, such as a driver's licence or a credit card which many poor people do not have. Utility companies often require a deposit as a condition of service. Employers may require prospective employees to purchase costly uniforms or supplies up front as a condition of employment. Low income individuals are denied loans, mortgages or accommodation based on perceived, rather than actual inability to pay or unreliability, despite evidence that it is those with more disposable income who tend to default on payments more frequently. ${ }^{4}$ Those with few resources, particularly those receiving social assistance, are subjected to harsh stereotypes. For example, Mike Harris, former Premier of Ontario, supported a reduction in social assistance to single mothers because he did not want any of their money to "go to beer." His party introduced an initiative to require mandatory drug testing for welfare assistance recipients, apparently upon the assumption that poor people are more likely to use drugs, or have less of a privacy interest than those not receiving public assistance. ${ }^{6}$ Low income individuals are often portrayed as authors of their own misfortune who can remedy their situation by simply working harder. This attitude even appears in judicial opinions. ${ }^{7}$ At the extreme, economically disadvantaged people are characterized as irresponsible parents with low morals and skewed priorities. ${ }^{8}$ Day-to-day activities that are taken for granted by those with economic means are barrier-laden in innumerable ways for those who are poor. ${ }^{9}$ Those living in poverty are often members of other marginalized groups, as poverty is frequently a result of other forms of inequality, such as those based on race or disability. ${ }^{10}$ Despite facing such strong barriers to equal participation in society, and despite being harshly stigmatized, poor people have no legal recourse for discrimination on the basis of poverty or social condition.

\section{WHAT IS SOCIAL CONDITION?}

The term "social condition" is vague at best, and if incorporated into Canadian law, would likely be a definition that evolves over time. Quebec is the only province in Canada that has

See J. Thomas Yacatto, Balancing Act: A Canadian Woman's Financial Success Guide (Scarborough: Prentice Hall Canada, 1996), in which the author challenges the myth that the solution to staying debtfree is to have more money. It is those with less money who tend to be more careful with it, and those with more who assume a false security and act less responsibly.

$5 \quad$ Canada, Justice Department, Promoting Equality: A New Vision: Report of the Canadian Human Rights Act Review Panel (Ottawa: Canadian Human Rights Review Panel, June 2000) (Chair: G.V. LaForest) online: Department of Justice, Canada <canada.justice.gc.ca/chra/en/ehrareview_report_ 2000.pdf $>$ at 102 [LaForest Commission].

6 "Ontario Election 1999," online: Alcohol Policy Network <www.apolnet.org/issue 10.html>.

7 For example, see Gosselin v. Quebec (P.G.), [1992] R.J.Q. 1647, in which Justice Reeves expresses the view that poverty is the result of personal shortcomings or characteristics, such as poor work ethic, rather than the result of societal factors or prejudice.

8 See LaForest Commission, supra note 5.

9 For a comprehensive view of poverty in Canada see Pat Capponi, Dispatches from the Poverty Line (Toronto: Penguin Books, 1997).

10. . David Schneiderman \& Charalee F. Graydon, "An Appeal to Justice: Publicly Funded Appeals and $R$. v. Robinson; R. v. Dolejs" (1990) 28 Alta. L. Rev. 873. 
included social condition in its human rights legislation. ${ }^{\text {" }}$ Quebec jurisprudence has defined it as having both subjective and objective elements. The objective elements involve a person's standing in society, which is often determined by his or her occupation, income or education level, or family background. The subjective elements are the perceptions drawn by others from these various objective points of reference. In Quebec, a complainant need not establish that all of these factors influenced the challenged decision, but it is necessary to show that as a result of one or more of these factors, the plaintiff can be regarded as part of a socially identifiable group and that it is in this context that the discrimination occurred. ${ }^{12}$ Quebec courts and tribunals have found social condition to include temporary conditions such as pregnancy and unemployment. ${ }^{13}$

Although Quebec is the only jurisdiction that specifically includes social condition in its human rights legislation, other provinces have related provisions. Alberta, ${ }^{14}$ Manitoba,${ }^{15}$ and Nova Scotia ${ }^{16}$ include "source of income" as a prohibited ground of discrimination. Ontario ${ }^{17}$ and Saskatchewan ${ }^{18}$ prohibit discrimination on the basis of "receipt of public assistance." Newfoundland ${ }^{19}$ includes the narrower "social origin" as a prohibited ground.

\section{Potential Scope of Social Condition Protection}

There appear to be two implicit views regarding what social condition human rights protection would and would not entail. The first would place implied limits on protection, so that refusals of services and accommodation that are based on a true inability of the complainant to pay for them would not be considered discrimination. The second would expand the concept of social condition to include positive economic rights. ${ }^{20}$ Interestingly, Quebec courts and tribunals have found that it would not be discriminatory to refuse accommodation if the applicant truly could not afford the rent, but it would be discriminatory if the refusal was founded upon a perceived inability to pay based on stereotypes about the level of responsibility of the applicant. ${ }^{21}$ In fact, practically all of the "social condition" cases in Quebec involve refusal of rental accommodation or services based on the perceived, rather

Québec Charter of Human Rights and Freedoms, R.S.Q 1977, c. C-12.

Russel W. Zinn \& Patricia P. Brethour, The Law of Human Rights in Canada: Practice and Procedure (Aurora: Canada Law Book, 2000).

Department of Justice Canada, Social Condition as a Prohibited Ground of Discrimination Under the Canadian Human Rights Act in Canada: Practice and Procedure by A. Wayne Mackay, Tina Piper \& Natasha Kim (Ottawa: Canadian Human Rights Act Review, 2000) online: Canadian Human Rights Act Review <canada.justice.gc.ca/chra/en/socond2.html>.

Human Rights, Citizenship and Multiculturalism Act, R.S.A. 2000, c. H-14.

Human Rights Code, C.C.S.M., c. H-175, s. 9(2).

Human Rights Act, R.S.N.S.1989, c. 214, s. 5(1).

Human Rights Code, R.S.O. 1990, c. H.19, s. 2(1).

Human Rights Code, S.S. 1979, c. S-24.1, s. 2(1)(m.1).

Human Rights Code, R.S.N. 1990, c. H-14.

It seems that writers on social condition do not make this distinction clearly. Some implicitly contend that social condition protection would not find a denial of service based on inability to pay to be discrimination, yet at the same time assume that this limited application would provide a remedy to complainants who, for example, can't afford a fee for a bank service. 
than actual, inability to pay of those in receipt of social assistance. ${ }^{22}$ These cases seem to suggest that discrimination would not have occurred if the landlord had refused to rent to a low income person if they truly could not pay. This view of the inherent limits of social condition discrimination claims are supported even by advocates for social condition inclusion. The LaForest Commission, which supported the inclusion of social condition in human rights legislation, quoted representatives from the National Anti Poverty Organization who submitted that "[ $\mathrm{t}]$ he issue here is not poverty itself but rather the gratuitous discrimination against the poor...." 23 The Commission later stated that "there is a difference between a valid justification for the refusal of a loan and a denial based on stereotypes about the poor," and

...at the very least, the addition of this ground would ensure there is a means to challenge stereotypes about the poor in the policies of private and public institutions. We feel that this ground would perform an important educational function. It sends out a signal about assumptions and stereotypes to be taken into account by policy-makers. ${ }^{24}$

This limited vision of social condition protection stops at the point of legitimate inability to afford goods and services. This inability, however, is arguably the essential component of poverty. Such protection might increase access to housing and accommodation if the only factor preventing access was the influence of stereotypes. It may also provide a remedy to complainants who are challenging policies such as a bank's requirement to present a credit card as a condition of opening an account, since this does not involve payment or affect the bank's profitability. It would ensure that everyone has the right to enjoy the benefits of the law or to compete on a rational basis in the market for goods and services, ${ }^{25}$ but certainly not on a substantively equal or accommodating basis. The line would be drawn when access is denied because the complainant cannot pay for services. In effect, they would be denied legitimately because of poverty.

\section{INCONSISTENCY WITH EXISTING HUMAN RIGHTS JURISPRUDENCE}

Would an approach to the implementation of social condition as a prohibited ground of discrimination that limits the concept of discrimination to the application of stereotypes be consistent with existing human rights jurisprudence? If the answer is yes, social condition would be treated differently than other forms of discrimination. While discrimination often involves the influence of myth and stereotype, "adverse effect" discrimination typically does not. Adverse effect discrimination was defined in the now famous passage from Ontario Human Rights Commission and O'Malley v. Simpson-Sears Ltd.:

See for example Quebec (Commission des droits de la personne) c. Whittom (1993), 20 C.H.R.R. D/349 (T.D.P.Q.), affirmed (1997), 29 C.H.R.R. D/1 (C.A. Que.), Quebec (Commission des droits de la personne) c. J.M Brouillette Inc. (1994), 23 C.H.R.R. D/495 (Trib. Que.), Quebec (Commission des droits de la personne) c. Gauthier (1993), R.J.Q. 253, 19 C.H.R.R. D/312 (Trib).

See Department of Justice Canada, Social Condition as a Prohibited Ground of Discrimination in Human Rights Legislation: A Review of the Quebec Charter of Human Rights and Freedoms by Lucie Lamarche (Ottawa: Canadian Human Rights Act Review, 1999) online: Canadian Human Rights Act Review <canada.justice.gc.ca/chra/en/socondl.html> 
[T] here is the concept of adverse effect discrimination. It arises where an employer for genuine business reasons adopts a rule or standard which is on its face neutral, and which will apply equally to all employees, but which has a discrimination effect upon a prohibited ground on one employee or a group of employees in that it imposes, because of some special characteristic of the employee or group, obligations, penalties or restrictive conditions not imposed on other members of the work force... An employment rule honestly made for sound economic or business reasons, equally applicable to all to whom it is intended to apply, may yet be discriminatory if it affects a person or group of persons differently from others to whom it may apply. ${ }^{26}$

In applying this analysis, a refusal to provide rental accommodation to a person with a low income out of a belief that low income individuals are unreliable, without considering actual ability to pay, would be a clear case of discrimination that the Quebec Charter of Human Rights and Freedoms ${ }^{27}$ prohibits. However, it would also be discrimination for a landlord to institute a neutral policy (for example, all tenants must pay $\$ 500$ per month), that had an adverse impact on people living in poverty who genuinely could not afford the rent, and who were a protected group. Once this prima facie claim of discrimination is established, the defence is quite strict. As articulated in British Columbia (Public Service Employee Relations Commission) v. British Columbia Government and Service Employees' Union (B.C.G.S.E.U.), ${ }^{28}$ (an employment law case), the defendant must prove three things. First, that the standard, rule or provision was adopted for a purpose rationally connected to the performance of the job. This standard is generally not difficult to meet. Next, the defendants must establish that the standard was adopted with an honest and good faith belief that it was necessary to fulfill the work-related purpose. Finally, defendants must show that the standard is reasonably necessary to the accomplishment of this legitimate work-related purpose. To meet this requirement, a defendant must prove that it is impossible to accommodate the individual or group without imposing undue hardship. This is clearly a very high standard. In the case of a landlord refusing to rent to an applicant who cannot afford the rent, the landlord would likely be able to establish rational connection and good faith. His objective is to profit, and charging rent is rationally connected to this objective. Charging rent is also necessary to achieve profit. Under the duty to accommodate, however, it is questionable whether marginal effect on profit would constitute "impossibility" or undue hardship. It is certainly possible to operate a business with a smaller profit level, and it is not impossible to stay in business while not profiting from each individual customer or tenant. Strictly applied then, refusing accommodation, services, or goods based on a complainant's inability to pay may, in absence of legislation to the contrary, constitute discrimination.

\section{VI. "UNFETTERED CAPITALISM" AS A BASIS FOR LiMITING SOCIAL CONDITION PROTECTION}

At first glance, the imposition of the doctrine of undue hardship on the pricing of commodities may seem preposterous. Considering interference in market-driven profit potential would appear to shake the very foundations of our market economy that is based on the premise that the market is a neutral ground upon which all citizens compete. While there may be some question as to whether this approach to discrimination would produce 
desirable results, assuming automatically that exclusion of the poor from market participation is not discrimination ignores the existing discrimination analytical framework. Moreover, it is perhaps an ingrained knee-jerk response to the vast consequences that such human rights protection would have in a capitalist, market-driven democracy. Capitalism and a market economy ensure inequality. Perhaps the mechanisms of this societal structure are so entrenched in our everyday life that we are convinced that it is the ultimate forum of neutrality - $\mathrm{a}$ basis of determination of access upon which discrimination cannot be found. Some would argue that only barriers to participation, such as racism or myths about ability to pay, should be removed through human rights legislation. Once removed, the bare market and supply and demand mechanisms are appropriate determinants of who gets what goods and in what proportions. While such an interpretation may be more practical and workable, it would have a limited effect on poverty per se.

Perhaps the bounds of capitalist assumptions have to be somewhat expanded in order to progress towards true substantive equality for poor citizens. The plight of the nation's poor is not most seriously affected as a result of being subjected to stereotypes. Although stereotyping is a factor, barriers to equality are raised by economic inequality - in effect, by being in the disadvantaged group. Equality would certainly include protection from prejudiced thinking against those in the group. However, truly effective social condition discrimination protection would recognize that true equality would mean addressing the disempowering component of the essential nature of being in the group in the first place namely, poverty. Simply removing the effects of stereotypes, or barriers that do not infringe upon marketplace profit potential addresses only one minor contributor to poverty. What is left, however, is impoverished people who are nonetheless excluded from accessing many goods, services, and accommodation by virtue of their social condition. Such a limited application may do little to even dent the infallibility of the capitalist marketplace, where the unequal distribution of wealth adversely affects those who are poor to the point that basic human requirements and human dignity are denied.

Even if one accepts that true substantive equality would dramatically affect the distribution of wealth in society, it would be naive to suggest that human rights legislation could significantly alter the basic tenets of capitalism and the laws of supply and demand. Human rights codes will not transform Canada into an egalitarian state. Economic rights therefore need to be distinguished from economic privileges, such as the ability to purchase a Jaguar. Inequities exist in all social orders, and it is foolish to presume a right to trade evenly in the global marketplace. For this to happen, those who are economically advantaged would have to essentially voluntarily sacrifice market power to those with less. This ideal, while perhaps noble, is unlikely to be realized. Substantive equality regarding social condition, realistically speaking, would target universal access to the necessities of life.

Even limiting the scope of what substantive equality that resulted in universal access to necessities of life would entail, its application in human rights legislation would be difficult. For example, would private retailers be required to accommodate through lowering their prices for customers who cannot afford to pay for essential goods that they sell? Again, while perhaps a noble goal, it is unrealistic. Rather than attempting substantive economic equality solely through human rights codes, social condition protection in the Charter may result in the "neutral" market yielding to fundamental human rights, such as necessities like food, 
shelter, employment and dignity. This, in principle, is not completely contrary to a capitalist economy as we do have publicly-funded employment insurance, pension plans and social assistance schemes. Some have said that addressing social condition in a truly substantive way would necessitate complementing anti-discrimination legislation with positive economic rights enshrined in the Charter, where the burden would be focused more on the public rather than private sphere. ${ }^{29}$

\section{LAYING THE FOUNDATION FOR ECONOMIC RIGHTS: INTERNATIONAL LAW AND CANADA'S OBLIGATIONS}

\section{A. INTERNATIONAL LAW}

The Universal Declaration of Human Rights includes in Article 22 the right to social security and to economic, social and cultural rights indispensable for dignity and the free development of personality. ${ }^{30}$ The International Covenant on Civil and Political Rights (ICCPR) $)^{31}$ came into force in 1976. As of July 2000, there are 145 state parties to the ICCPR, including Canada. The International Covenant on Economic, Social and Cultural Rights (ICESCR $)^{32}$ also came into force in 1976, and is perhaps the most significant document on economic rights. Article 9 recognizes the right to social security. The rights to an adequate standard of living, including adequate food, clothing, and housing, and the continuous improvement of living conditions are articulated in Article 11. Article 12 guarantees rights to the highest attainable standard of physical and mental health. Although there is no right to individually petition under this covenant, national compliance is monitored and reported on every five years by the Committee on Economic, Social and Cultural Rights. ${ }^{33}$

Treaties do not have direct effect in Canadian law unless they have been incorporated into domestic law. ${ }^{34}$ However, in absence of direct incorporation, rules of treaty interpretation dictate that it is assumed that countries signed on in good faith and intended to uphold treaty provisions. There is also an accepted presumption of conformity and harmony between international and domestic obligations. If there is more than one possible meaning of a statutory provision, it should be read in conformity with international law. Consequently, judicial interpretation of Canada's existing legislation should, whenever possible, conform to international treaty obligations. ${ }^{35}$

Commentators seem to hold the conflicting view that discrimination would not occur when denial of service was based on a bona fide inability to pay. At the same time, they assert that social condition protection is necessary to grant a remedy to those who cannot afford such up-front fees. These two ideas seem to conflict. It seems that there is a widespread assumption about the limits of social condition protection, yet a recognition of the need for it to extend further, but little recognition of the conflict in such analysis. 19 December 1966, 999 U.N.T.S. 171, (entered into force 23 March 1976, accession by Canada 19 May 1976).

Ibid.

34 See Francis v. Canada, [1956] S.C.R. 618 at 621; Capital Cities Communications v. Canadian RadioTelevision Commission, [1978] 2 S.C.R. 141 at 172-73. 


\section{B. JUDICIAL REFERENCE TO THE RELEVANCE OF INTERNATIONAL HUMAN RIGHTS LAW}

In light of Canada's obligations to favour judicial interpretation that conforms to international obligations, it would appear that social condition should be incorporated into Charter analysis. However, despite some judicial recognition of international obligations regarding social condition, and with a few positive exceptions, the courts in Canada appear hesitant to extend Charter protection to include economic rights, perhaps out of the same concerns that would likely limit human rights anti-discrimination protection.

The courts have not completely ignored international law, either in general, or in relation to economic rights. In $R$. v. Oakes, ${ }^{36}$ the Supreme Court of Canada's proportionality analysis of s. 1 of the Charter was partly informed by European human rights law. In British Columbia (Superintendent of Motor Vehicles) v. British Columbia (Council of Human Rights), ${ }^{37}$ and in Rodriguez v. British Columbia (A.G.), ${ }^{38}$ both s. 7 Charter cases, the court made reference to international human rights law. In Slaight Communications $v$. Davidson, ${ }^{39}$ the Supreme Court of Canada found that international human rights law should inform the interpretation of Charter rights. The same Court in $R$. v. Keegstra, ${ }^{40}$ a case about racial discrimination, looked to the ICCPR to inform its analysis of racism. In $R$. v. Ewanchuk, L'Heureux-Dubé J. stated that the "Charter is the primary vehicle through which international human rights achieve a domestic effect."

\section{Judicial Recognition of Social Condition}

Regarding the application of international economic rights, in Slaight Communications, Dickson J. mentioned the right to work under ICESCR as an aid to interpreting the Charter. ${ }^{42}$ In Irwin Toy Ltd. v. Quebec (A.G.), the Supreme Court of Canada said that it would be "precipitous" to exclude from the Charter economic rights such as those guaranteed in international documents. ${ }^{43}$ However, other Supreme Court and lower court decisions appear to shy away from the explicit implementation of economic rights in domestic Charter jurisprudence. In Fernandes v. Director of Social Services (Winnipeg Central), ${ }^{44}$ for example, the Manitoba Court of Appeal denied the s. 15 claim of a man who was denied special assistance to pay for attendant care without which he would be forced to leave his home and live in a hospital. The denial was on the ground that there was no basis upon which

commented on this issue by holding that a statute is presumed to be consistent with international law. A law may validly contradict international law, but ambiguity should be read in conformity with it. See Daniels v. White, [1968] S.C.R. 517 at 541. This principle was also invoked in Salomon v. Commissioners of Customs and Excise, [1967] 2 Q.B. 116 at 143-44 (C.A.), and in Baker v. Canada (Minister of Citizenship and Immigration), [1999] 2 S.C.R. 817.

[1986] 1 S.C.R. 103.

[1999] 3 S.C.R. 868.

[1993] 3 S.C.R. 519.

[1989] 1 S.C.R. 1038 [Slaight Communications].

[1996] 1 S.C.R. 458.

[1999] 1 S.C.R. 330 at para. 73.

Supra note 39.

[1989] 1 S.C.R. 927 at para. 95.

(1992), 78 Man. R. (2d) 172 (C.A.). 
he could validly assert a right to the assistance. Similarly, in Conrad (Guardian ad litem of) v. Halifax (County), ${ }^{45}$ a single mother was denied interim assistance to cover basic necessities pending an appeal of a termination of assistance. The Court found that the Charter cannot provide protection of economic interests of this sort. ${ }^{46}$ In Re Dunmore et al. v. Ontario (A.G.), ${ }^{47}$ the Court found that economic disadvantage alone is not sufficient to show that $\mathrm{s}$. 15 Charter rights are infringed.

Some courts have come to the disturbing conclusion that economic rights are not rights at all, but are policy issues that are best mediated by the legislature. Gosselin c. Québec (P.G.) ${ }^{48}$ was a Charter challenge to a Quebec Social Aid Act ${ }^{49}$ involved regulation. The challenge was brought under ss. 7 and 15 of the Charter $^{50}$ and s. 45 of the Quebec Charter. ${ }^{51}$ Section 29(a) of the Quebec Regulation respecting social aid made the amount of benefits for single employable people under age 30 conditional on participation in "employability" programs. ${ }^{52}$ Section 29(a) of the regulation set the base amount of welfare payable to persons under the age of 30 at one third of the base amount payable to those 30 and over. This reduced welfare payments to those between 18 and 30 to $\$ 170$ a month. Participation in one of three education or work experience programs allowed people under 30 to increase their welfare payments to either the same as, or within $\$ 100$ of, the base amount payable to those aged 30 and over.

The Court both at trial and on appeal found that there was no right to adequate financial assistance under the Quebec Charter or the Canadian Charter. When addressing the requirements of ICESCR, the Court said that because the right is subject to "progressive realization," it "signifies mere intent" or policy objectives of the government rather than an enforceable human right. The result was recently affirmed by the Supreme Court of Canada. ${ }^{53}$ The majority held that the facts did not establish a breach of s. 7. However, six out of the seven majority judges held that on the right set of facts, the Charter could result in the imposition of positive obligations on the government. Justices Arbour and L'Heureux-Dubé dissented, finding that s. 7 was breached. In a strongly worded dissent, Arbour J. held that in some circumstances, the Charter may impose positive obligations on the government where to not do so would have an impact upon one's basic health and survival. To interpret the Charter otherwise, she argued, would be inconsistent with the view of Canada's Constitution as a "living tree."

[1994] N.S.J. No. 137 (C.A).

Ibid.

(1997), 37 O.R. (3d) 287 (Ont. Gen. Div.). The Supreme Court of Canada allowed the appeal, but because of its conclusion on other grounds, did not find it necessary to comment on s. 15. Justice L'Heureux-Dubé in dissent mentioned that agricultural workers could be considered a protected group under s. 15. See [2001] 3 S.C.R. 1016.

(1999) J.E. 99-941 (C.A.) [Gosselin].

L.R.Q., 1988. C. A-18 since replaced by the Act Respecting Income Security (c. S-3.1.1) (1988, c. 51, s. 92).

Supra note 2.

Supra note 27.

R.R.Q., 1981, c. A-16, r. 1.

2002 SCC 84 [Gosselin]. 
In Masse v. Ontario (Ministry of Community and Social Services), ${ }^{54}$ the Ontario Court, General Division followed the reasoning of the trial judgment in Gosselin in which several social assistance recipients challenged a 21 percent decrease in social assistance. The Court accepted the government's arguments that the plight of the complainants resulted from their failure to provide for themselves; that while poverty is a serious issue, there is no right to social assistance or a minimum standard of living protected by the Charter and that the Charter does not confer any affirmative right to government aid, as poverty issues are a matter of public policy rather than human rights. In Egan v. Canada, L'Heureux-Dubé J. seemed to deny the place of economic rights in the Charter:

The Charter is a document of civil, political and legal rights. It is not a charter of economic rights. This is not to say, however, that economic prejudices or benefits are irrelevant to determinations under s. 15 of the Charter. Quite the contrary. Economic benefits or prejudices are relevant to s. 15, but are more accurately regarded as symptomatic of the types of distinctions that are at the heart of s. 15: those that offend inherent human dignity. ${ }^{55}$

The implication appears to be that racism, for example, which results in the "symptom" of economic disadvantage, is a s. 15 concern that involves dignity, yet the economic disadvantage in itself is not worthy of human rights protection.

In light of Canada's obligation to ensure economic rights, there is perhaps more resistance on this ground than on any other. Although the court in Eldridge v. British Columbia (A.G.), ${ }^{56}$ and the Supreme Court's dissenting judgments in Gosselin ${ }^{57}$ arguably opened the door slightly toward requiring the government to proactively provide services, it is possible that hesitance rests on the fear that opening this door any further would result in massive spending requirements on the government and skew societal priorities in favour of the most litigious. ${ }^{58}$ Some fear that enshrining economic rights may usurp legislative sovereignty by allowing human rights tribunals to order governments to create social security programs and to modify existing ones. ${ }^{59}$ These fears are likely unfounded. Positive obligations would not require the courts to become policy-makers by examining every piece of legislation to ensure that the government is providing enough. It would simply mean that

Canadian courts, like U.N. human rights treaty monitoring bodies, can consider the broad systemic pattern of social and economic disadvantages as being central to the equality guarantee. Where adequate programmes or legislation are necessary for the protection of fundamental human rights linked with dignity and personal

(1996), 134 D.L.R. (4th) 20 (application for leave to appeal to Ont. C.A. and S.C.C. dismissed). [1995] 2 S.C.R. 513 at 544.

[1997] 3 S.C.R. 624.

Supra note 52.

See e.g. Andrew Petter, "Immaculate Deception: The Charter's Hidden Agenda" (1987) 45 Advocate (B.C.) 857. See also Kearney v. Bramalea Ltd., [1998] O.H.R.C.B.I. No. 21 at para. 179, where the tribunal found that refusal of rental accommodation based on a perceived inability to pay that was not based on reality would be discrimination, but general economic inequalities are irrelevant, because acting on this basis would require the board to order a "wide scale affirmative action program."

Department of Justice Canada, Social Condition - Literature Search by Helen Berry \& Mimi M. Lepage, (Ottawa: Canadian Human Rights Act Review, 2000) online: Canadian Human Rights Act Review <canada.justice gc.ca/chra/en/socondlit.html>. 
integrity, [the Charter] will require governments to meet certain substantive obligations in the implementation of the necessary legislation and programmes. ${ }^{60}$

The necessity of moving human rights provisions further along was articulated by Bastarache J.A. at the New Brunswick Court of Appeal. ${ }^{61} \mathrm{He}$ held in dissent that full realization of human rights cannot be limited to preventing government intrusion upon individual rights, and that some rights required positive government action. He said that this would not mean that judicial intervention would be necessary in all policy choices, only in those limited cases when individuals can make legitimate claims against the state in the name of liberty and human dignity.

\section{IS The Charter the Proper Place fOR THE Protection OF ECONOMIC Rights?}

Although the courts seem reluctant to interpret the Charter as extending to economic rights and discrimination protection regarding social condition, if protecting economic rights is taken seriously as an international obligation, the Charter may be the best and least "threatening" place to do so. Positive obligations to ensure access to basic necessities may be more appropriately assigned to the public sector. ${ }^{62}$ The line between negative and positive rights is not always clear. Prohibition of discrimination, if applied to its full extent, may have the implicit effect of creating a positive right if the only thing preventing a claimant from accessing the goal in question is discrimination. However, as the Quebec example has illustrated, an anti-discrimination model regarding social condition would likely be interpreted so that effective indirect provision of positive rights in this way is avoided. It would be unlikely, for example, that human rights legislation would require private businesses to charge "sliding scale" prices for goods and services. A Charter right to life's basic necessities - perhaps included in the $\mathrm{s}$. 7 right to security of the person, or by including poverty or economic disadvantage as an analogous ground under s. 15 would in limited cases, mediate the assumed "neutrality" of the market by not shaking the position of the market per se. Rather, it would equip all citizens with at least the basic tools required to be effective participants in the market. Such a move is central to the mission of the Charter and human rights legislation. ${ }^{63}$ This approach, while placing the ultimate responsibility for social condition protection on the public sector, would neverthleless mean that the private sector would also play a role. If the government enacted rent control legislation, for example, it would be an equality-seeking measure, the cost of which would be borne largely by private sector landlords.

Bruce Porter, "Judging Poverty: Using International Human Rights Law to Refine the Scope of Charter Rights" (2000) 15 J.L. \& Soc. Pol'y 117 at 152.

New Brunswick (Minister of Health and Community Services) v. J.G. (1997), 187 N.B.R. (2d) 81

The LaForest Commission's point of hesitation regarding the inclusion of social condition was the allocation of responsibility on the private and public sectors, recognizing the difficulties in imposing obligations to provide food and housing on the private sector (supra note 5).

Brian Etherington, "Promises, Promises: Notes on Diversity and Access to Justice" (2000) 26 Queen's L.J. 43. 


\section{Conclusion}

There can be little argument that the effect of poverty is far-reaching, leading to the disenfranchisement of a large segment of our population. Poverty is unique in that it is both a result of other forms of discrimination, such as racism and disability, and a cause of disadvantage. It is also unique in that, given our capitalist, market-driven economy, economic inequality will never be eradicated, but is considered a hallmark of our democratic free market. Poverty protection in human rights legislation, because of its uniqueness, would require a different approach. If social condition analysis was undertaken within the existing discrimination analysis, social condition protection would be substantive and far reaching, and would even recognize as indirect discrimination a refusal to sell, rent or provide based on a person's true inability to pay. While this might be a noble goal in addressing poverty, it is unlikely and impractical to expect that human rights legislation will be a tool through which the private marketplace moved from profit motive to accommodation motive. However, the stronghold of capitalism may be slightly bent to yield to the protection of fundamental human rights if, in addition to a limited form of human rights legislation protection, positive economic rights were interpreted to exist under the Charter. This would place any economic and logistical burdens associated with preserving those rights broadly on the public sector, and indirectly on the private sector. This could be accomplished without altering legislation or an analytical framework, and would bring Canada more in line with its international human rights obligations. It could also be accomplished without prohibitive cost, especially when the cost of ensuring some rights, such as the right to affordable housing, could be distributed widely among the public and private sector, such as through government subsidies and rent control legislation.

While there are many questions about how social condition would operate in human rights law, and while much would have to be sorted out through an ongoing dialogue between the courts and the legislature, perhaps the most pressing barrier is attitudinal. Until current judicial and societal attitudinal condition are swayed towards accepting the importance of fundamental human rights, social condition will remain a source of crushing disadvantage. 